\title{
北米の大学図書館におけるWeb2.0以後の 变化
}

\author{
情報リテラシーに与えた影響
}

Changes in academic libraries in North America since Web2.0

Impact on information literacy

野口 契子 1

\section{NOGUCHI Setsuko'}

1イリノイ大学アーバナ・シャンペーン校 アジア図書館

1 Asian Library, University of Illinois at Urbana-Champaign (325 Main Library, 1408 West Gregory Drive, Urbana, Illinois 61801) E-mail : enoguchi@illinois.edu

原稿受理 (2008-11-26)

(情報管理５1(10):733-742)

1. Web2.0の定義と情報リテラシー

Web2.0という言葉が巷の話題にのぼるように なつて数年経つ。Web2.0の概念については，あい まいでわかりにくいと言われているが，一般的に ティム・オライリーが2005年に「Web2.0」を提唱 した概念が最も頻繁に引用されている1)。これは Webの世界に新しく見られるWebサイトやその サービスの変化を特徵付けてとらえたもので, 斬 新であるとともに巨大, かつ流動的なWebの変化 の実態をよくとらえている。

このWeb2.0とそれに関連する技術の影響力は企 業, 学術などあらゆる面にわたっているが, 筆者 が勤務する米国の大学図書館の世界においても, わずか $1 \cdot 2$ 年の間にいろいろな面でWeb2.0により もたらされた変化が見られ，今や主流とまで言わ れる。また，米国において見られる変化の方が，日 本における変化より大きいように見受けられる。 これは筆者の私見であるが，米国よりはるかに狭
い国土で情報の行きわたる速度が速く，しかも技 術面で米国より先を行く日本におけるテクノロ ジーの衰勢の速さと，アイディアや新しい技術が 生まれてもそれが社会全般に浸透していく速度の 遅い米国においての現象の違いではないだろう か。技術の伝播が遅い分，それが行きわたるまで の間に多民族や各層における文化を取り入れつ つ，大きくまた柔軟に形成していくのが米国での 現象亡思われる。ここでは，米国における図書館 の事例を中心として，Web2.0のもたらす環境のも とで新しいリソースや情報の形から得られる膨大 な情報量をいかに取り入れリサーチに反映させて いくか，また，利用者に情報を得る上での注意を どのように喚起するかという情報リテラシー面に 着眼したい。

まず,オライリーが定義したWeb2.0の特徵とは, 1. The Web as platform, 2. Harnessing collective intelligence, 3. Data is the next Intel Inside, 4. End of the 
software release cycle, 5. Lightweight programming models, 6 . Software above the level of a single device, 7. Rich user experienceの7点であるが，実はこのど れもが情報リテラシーの観点からみれば諸刃の剣 となると筆者は考える。

1. The Web as platform（プラットフォームとして のWeb)

パソコンのデスクトップ上で行われていた検索 や研究・創作活動などの作業がWeb上で行われる ことにより，プロジェクトへの参加が容易になり 参加する人数が増える。提供される情報の速度も 速い。しかし，プロジェクトの管理がしつかりし たものでなければ，確実に情報が保存されるとい う保証はない。Webサイトが移動，消滅する可能 性もある。

2. Harnessing collective intelligence (集合知の利用) Web2.0の代表的な特徵の一つが「集合知」であ る。この集合知は，従来の権威あるタクソノミ一 による体系的な分類法による情報の管理ではな く, 人々が提供しあう知識により関連付けられる, フォークソノミーと呼ばれる分類体系で管理され ることが多い。従って，広範囲にわたる語彙が集 積したデータベース等のリソースの提供が可能で ある。その一方で，内容に対する信頼性への疑問 も存在することは言うまでもない。

3. Data is the next Intel Inside（データは次世代の

\section{“インテル・インサイド”)}

Webの核となるものはデータであり, 独自性が あり優れたデー夕を所有し，かつ有効に提供する ことが重要である。しかも，デー夕は頻繁に変化 する可能性が高い。所有するデータの持つ特性亡 その将来性を考えてどのように管理・運営するか によって価值も変わってくる。情報を高い精度で, プライバシーや著作権に至るまで念頭において管 理するというのは実はかなり難しい。
4. End of the software release cycle（ソフトウェ ア・リリースサイクルの終焉）

今までのように難解なプログラミングではな く，簡単なプログラミングが可能になりソフト ウェア面でも作業面でも低コストで情報を提供で きるようになった。更新も速くなり，利用者は常 に新しい情報を得ることが可能である。一方で, 手 軽なソフトウェアの変更により，提供される情報 内容や形式の変化もあり得る。情報を発信する側 は何がより求められるサービスなのかを判断して いかなければならない。そのためには，利用者と のコミュニケーションや提供する情報の宣伝も必 要になってくる。

5. Lightweight programming models（軽量なプロ グラミングモデル) および

6. Software above the level of a single device (単 一デバイスの枠を超えたソフトウェア)

Web2.0の技術によりパソコンだけではなく，携 帯電話や，BlackBerry，iPodも端末として情報を入 手，発信できるようになった。これらの手軽で軽 量，持ち運びのできる媒体により，情報はパソコ ンのある部屋の中だけでなく, 利用者と行動をと もにするようになった。日本においては携帯電話 の技術が米国より早期に発展したため, 特に新し い変化とはとらえられていないが，米国において はこの現象は，従来コンピュータの利用に習熟し ていた層以外のさまざまな利用者からも，より広 範囲な情報が求められるようになり，それに呼応 して多様な情報が提供されるという飛躍的な変化 を引き起こしている。利用者から求められる情報 の精度, 更新速度への期待も高くなっていくので, 不必要な情報を避け，何が求められているかを常 に念頭において運営をしなければならない。また 利用者側から見ると，技術の発達によりもたらさ れた手軽さが，ともすれば情報源などの認識を希 薄にさせる危険がある。 
7. Rich user experience（リッチなユーザー経験）

これは, JavaScriptやAjaxなどのアプリケーショ ンを実装することが簡単になり，それによって利 用者のアクセシビリティも向上するというもので ある。例えば, GoogleではWeb上で運営できるカレ ンダーをはじめとするグループ作業ツールを提供 しているが, どこからでもアクセスできる操作の 容易なサービスは，ビジネスや学校関係でも利用 者が多い。一方でセキュリティの問題が重要視さ れている。最近のGoogle Mapsにおける個人情報の 流出がその例である。

このように, Web2.0の特徵として, サービスす る側は比較的低コストでデー夕を提供することが でき，ユーザー側は手軽に利用，また膨大な情報 量, あるいは専門的なデータの入手が可能である と同時に，今までにも増して，情報をいかに速や かに正しく判断し, 利用するかといったリテラ シーの実践が必要になってくる。

\section{2. ソーシャル・ネットワーク}

以上挙げてきた中で，情報リテラシーの面から 見たWeb2.0環境での最も顕著な動向は, ソーシャ ル・ネットワークの発達に尽きると言っても過言 ではない。Nielsenの統計によると，2006年には MySpaceをはじめとする米国トップ10のソーシャ ル・ネットワークのサイトにアクセスした利用者 の数は6,880万人に上り，これは前年に比べて47\% 増とされる2)。この飛躍的な数字の増加は, 必要な 情報に即アクセスできない広大なアメリカの地方 都市に住む人々にとって, ソーシャル・ネットワー クを通じての何らかのコミュニティーへの参加が 魅力的であり，かつ情報収集が容易になったこと を示していると筆者は見る。

ソーシャル・ネットワークには, 不特定多数の
人々によるものと, ある特定の分野の人々によっ て作成される特化型のものとがある。前者におい て，Web情報の主導権が管理者／発信者から参加 するユーザーに移り変わりつつあることは，すで に指摘されている。ティム・オライリーが挙げて いるWeb2.0の7つの特徵のひとつである「集合知の 利用」はソーシャル・ネットワークによって集め られた集合知を指す。例としては, Amazonや LibraryThingが挙げられる。図書館はどちらかといえ ば後者の特化型に属するが, 図書館という性格か ら，収集した資料・情報を，利用者とコミ二ュケー ションをとりつつ提供していくスキルは他に勝る ものがある。blogやRSSを発信する図書館のホーム ページは米国では，もはや一般的に見られるもの である。

ソーシャル・ネットワークにより，情報量は驚 異的に飛躍し多様化した。また，溢れ出てきた情 報はまたたく間に伝播し，浸透していく。最近で は情報を発信する側も利用する側も，情報に対す る意識が次第に洗練されつつあり，よりよいデー 夕を集積しようとする傾向がある。その反面, 意 図的にしろ無意識にしろ, 操作された情報が横行 する危険性を常にはらんでおり, むしろソーシャ ル・ネットワークの特性を悪用されることもある。

\section{1 ソーシャル・ネットワークの利点}

ソーシャル・ネットワークの利点をまとめてみ ると，収集された情報は今までにない巨大な情報 源を作り上げ，広範囲の利用者に提供できるよう になるということに尽きる。時差や言語の壁によ る多少の障害はあるにしても, 情報提供源の垣根 がなくなり，多種多様なリソースが短時間でまと まる。また，先に述べた特定の利用者による特化 されたwikiなどの作成により，学術的なコミュ二 ティーによる高度な集合知が形成される。企業や 
研究所はWeb2.0を利用し，R\&Dの向上を図ること もできる。

\section{2 ソーシャル・ネットワークの問題点}

言うまでもないことだが, Web上で提供される 情報は修正・複製が可能である。簡単に入手, 改 ざんできる情報を剽窃する事例は多い。これは, ソーシャル・ネットワークの中で提供される情報 に対し，手軽感から感覚が鈍るからではないかと 思われる。利用者が意図せずして同じアイディア, 言葉を使用する可能性も大であるが，見極めはき わめて難しいと言える。従って著作権問題はより 複雑になるであろう。

また，目に見える部分と見えない部分を認識す るのが困難であるという盲点が挙げられる。例え ば，情報を検索する際に使用する自分の知識内の 語彙による検索結果は,すべてを網羅したもの，あ るいは精度の高いものではない可能性がある。要 するに自分の語彙では検索結果に現れない情報も 多いのだ。しかし，われわれはともすれば検索結 果を追うことにとらわれ，結果に現れない部分に ついての存在の可能性を忘れがちになる。フォー クソノミーについても同じことが言える。多数の 人々が使用する言葉であるからといって，すべて が正しい語彙であり，すべての人に使われるとい うわけではない。

最後に虚と実の部分の可能性が挙げられる。blog やMySpaceなどは, 著作者／発信者が自由に著作／ 発信する権利を持っているが，同時に虚飾の世界 を展開できる場でもある。また直接的，婉曲的な 誹謗や中傷の場にもなり得るし，扇動的な言動の 場にもなる。筆者はWebで入手した全く根拠のない 情報を信じ，他の人々にそれを発信する人々を学 生のみならず社会人の間にも多く見かけている。

\section{Library 2.0}

それでは，図書館においてWeb2.0はどのような 影響を与えているか。一般的には，Web2.0の技術 を利用して利用者重視のサービス向上を図る図書 館もしくはそのサービスを「Library2.0」と呼んで いるが, Web2.0と同様にLibrary2.0についても定義 は明確でない。特に図書館離れが進む利用者の確 保を目的として開発される面もあり，また，経済 状態の悪化による慢性的な人手不足の解消にも役 立っている。blogによる図書館の二ュース発信，イ ンスタント・メッセージを使ったヴァーチャル・ レファレンスや，iPodを使用した図書館のヴァー チャル・ツアーなどのサービスは, 米国の大学図 書館ではもう目新しいものではなくなってきてい る。これらについては日本でもいくつか例が見ら れるので，ここでは新しい事例として，次世代 OPAC, Second Life, Web典拠ツールの3点を報告 し，情報リテラシーの面から検証したい。

\section{1 次世代OPAC}

Library2.0の例として，米国で現在最も注目され ているのは次世代OPAC ${ }^{3)}$ であろう。書籍等の力 バーの写真, 自館を含めた地域図書館の所蔵の有 無，著者や主題による関連するレコードのリスト， タグの利用, 網羅的な検索, OPACから得られる情 報のカスタマイズなどが次世代OPACの特徵とさ れる。当初はソーシャル・ネットワークが大きな 特徵とされ，利用者による夕グ付けが話題になっ たが，最近では疑問視する向きもある。口火を切っ て始めた図書館で思ったほどの利用がなかったこ とから, 多くの参加者が望めないのではないかと いった声である。タグが多く付けられるのは，ア ニメやコミック，日本のカルチャーばかりという コメントも目にする4)。実際に，イリノイ大学の日 
本語のコレクションを考えた場合，言語の問題や 利用者の数から判断すると多くの夕グは望めな い。また，根本的に次世代力タログの基本となる 図書館のOPAC自体がどこまで精度が高いかとい う問題もある。しかし, 次世代OPACがAmazonの提 供するような利用者中心のサービスを提供する OPACへと変化していくのは間違いない。

\subsection{Second Life}

次に, 日本の図書館ではまだあまり見られない 例としてSecond Lifeがある。Second Lifeとは最近日 本語版も出た3Dオンライン仮想空間でアバターが 学校やビジネスの場で仮想の生活をしているもの だが, アメリカ図書館協会（ALA）はALA Island と いうヴァーチャル・コミュニティーをSecond Lifelこ 発足, ALA Island Story Hour Garden ${ }^{5)}$ という名称で, 本の紹介やイベントの場を開始している。仮想世 界でのゲームとストーリーテリングを組み合わせ た試みや，話題作の著者のALA Island訪問，選書の 自由を語る禁書週間などなかなか充実した内容に なっており, ALAはこれからもこのヴァーチャル コミュニティーを発展させていくだろう。筆者の 勤務するイリノイ大学図書館でも, 実際のライブ ラリアンがアバターとなりSecond Lifeの中でレ ファレンスサービスを行っている。また同校のラ イブラリースクールでは, Second Lifeにおいてどの ように図書館や博物館を管理運営するか, Second Life内でのクラスにおける教授法といつた講義を 提供している。一方で, Second Lifeにおいて活動し ているアバターたちが仮想の人間であること, 仮 想世界においても通貨が存在しビジネスが行われ ていることを私たちは忘れてはならない。損得の 生じる世界において虚偽の風説や犯罪が発生する ことは十分あり得るからである。

\subsection{Web上の典拠ツール}

Web上で引用文献や参考文献等の典拠を作成， 管理する新しいツールとして, RefWorks, EndNote Web, Zoteroなどが使用されている。米国の大学で は，図書館のサイトを通じて提供されることが多 く, 活用方法についてのワークショップも実施さ れる。これらのツールは, Webの特性を活かして 手軽にアクセスし，必要な典拠情報をデータベー スからインポートし管理できるという特徴を持 つ。また，パスワードによるメンバーのアクセス が可能であり, 情報交換や共通のデータベース構 築の場ともなる。しかし，書誌的な情報の典拠記 述は信頼できるものかという根本的な問題が残 る。図書館のデータベースからインポートした書 籍や論文記事の記述に誤りがある可能性もある。 また, 論文の中で引用されている情報がすべて正 しいという保証はない。論文の中で引用した情報 は，必ず一次資料にあたって確認するという契約 を著者と出版社の間で交わすべきだという考えも 出てきている6)。

上記で述べた次世代OPAC, Second Life, 典拠ツー ルはいずれも利用者の参加を想定しているが，同 時に監督責任者やコーディネーターの関与も大な り小なり必要とする。精度の高い結果を求めるの であれば教育の一環としてリテラシーも要求され る。これは正確性を保ち高度な情報を提供すると いう図書館の性格からくるものである。また，専 門的な知識や言語の知識が要求されるものについ ては，特にサブジェクト・ライブラリアンの役割 が重要になる。 


\section{4. 学術コミュニケーション}

\subsection{Web2.0と学術コミュニケーション}

デジタル化したデータのリポジトリの構築と オープン・アクセスの必要性は以前より討議され ているトピックである。最近は, Web2.0の特性を 学術コミュニケーションの場に取り入れて, さら に情報の拡大・発展を図ろうという動きがある。 ARL (American Research Libraries) は学術コミュ二 ケーションに関する米国の大学のWebサイトと blogの一覧を発表し, 現在見られる形式について報 告している7)。このレポートは教育機関がどのよう にこういったWebを利用しているか，教授たちが どのように電子出版を利用しているかなどをリ サーチしたもので, 米国の大学図書館において Webにおける学術コミュニケーションが今や必須 であることを示している。また，研究機関の傘下 にあって発信されるWebサイトやblogが大量に存 在するなか，各サイトにおいて提供される関連す るリンク情報以外に，これらの分散する情報を主 題ごとにまとめ系統立てて提供するのも利用者の 立場に立つ一つのコミュニケーションの方法では ないか。これにはやはり，サブジェクト・ライブ ラリアンの能力に期待したい。

\section{2 学術出版}

米国における高等教育の場では，査読制のある 学術出版における発表が強く求められるが, 出版 までに時間がかかる，発表の場に限りがあると いった問題がある。そこで, 短時間で多量に発信 できる, 読者の参加の場がある8)などのWeb2.0の技 術を利用して, 研究者の出版の機会を高めようと する動きがある。しかしこれは従来の学術出版の 性格を変えかねないもので，当然歓迎する意見亡
反対する意見がある。発表の内容をどう検証する か, さらに発表された論文を学術出版として評価 するか否かが大きな問題となる。また，どのよう に論文やそのデータを保存するかも考えなければ ならない。一方，デジタル化され保存されている データの追跡は紙媒体に比べてはるかにたやすく なり，盗用や剽窃の防止にもなる。今後，この動 きがデジタル時代の学術出版を変えていくことに なるのか，注目されるところである。

\section{5. 情報リテラシー}

Webを媒体として提供される情報のためのリテ ラシーの重要性は，今までも論議され実践されて きた。しかし，Web2.0の時代に入り，よりWebに 特化した情報リテラシーが求められるものとなっ た。これは，今までのWebの評価基準では対処し きれない部分がでてきているからである。例えば, 集合知により集積された膨大な量と種類の情報を どのように判断し，利用するか，またソーシャル． ネットワークというWeb2.0の特徵をどのように理 解し有効な手段として利用するかといった点であ る。

\section{1 今までのWeb評価基準と新しい評価基準の 必要性}

先にも述べたようにWeb2.0の浸透とともに新し い基準も必要になってきていると筆者は考える。 ここでは，今までのWeb評価基準を表記し，かつ 筆者が実際に学生に指導する際に新たに付け加え る注意点を例として述べたい。

まず，これまでのWebの評価基準であるが，例 として以下にKapoun（1998）の提唱した基準を挙 げたい9)。

1. Web資料の正確性，2.Web資料の責任表示，3. 
Web資料の目的， 4. Web資料の作成日時や更新の 頻度, 5. Web資料の範囲。

この評価基準は現在もWebを評価するにあたり 基本となるものであるが，さらに筆者は以下の項 目を付け足している。

1. URLのドメイン名から典拠の権威を判断する。英 語のドメインと日本語, 他言語における形式の 違い(教育機関を表すacとeduなど）にも注目す る。

2. 本文の精度は高いか, 誤字や文法の誤りはない か。短時間のうちに更新, 配信される情報の中 には文章の質の低いものが存在する。

3. 頻繁な更新が行われているかをチェックする。 更新日が記載されているか, 最終更新日はいつ か。更新された日と自分の求める情報に最適な 日付との間に矛盾が生じないか。

4. 責任表示の有無を見る。トップページだけでは なく, どのページにも責任表示があるか。ある いはページの母体となるページへのリンク先が 記載されているか。例えば, 元のページから独 立したページの中には, 一見, 誰によっていつ 作成されたものなのかが不明なものが多い。

5. リンクの数を見る。リンク先が適正なものであ るか, またリンク切れがないか。

6. 履歴やノートがあるか。

7. 統計データなどの資料があれば，そのデータの 信用性を見る。典拠が記載されているか。Web 上で得られるデータは一次情報でない場合が多 い。

8. 脚注があるか。脚注に記載されている情報源の 適切性と, 情報の信憑性を見る。Webに記載さ れる脚注はWebの引用の典拠が多いが, リンク などを確かめる。

たとえ，学術情報を発信しているサイトであつ ても, 所属機関名, 著者名, 作成日や更新日のな
いサイトの評価は下がる。

また，筆者がよく使用する例はwikiやblogについ ての検証である。文献資料として認められない風 潮が一般である反面, 両方とも他の有効な情報源 としての利点も持つため, 後述の項目が判断の材 料になる。wikiに関しては, ソーシャル・ネット ワークと共通して，不特定多数の人々によって作 成されるwiki之，ある特定の分野の人々によって作 成される特化型のものとがある。前者のタイプの wikiにおいてよく挙げられる例がWikipediaで，言う までもなく集合知を利用して製作される大規模な 百科事典である。紙媒体で出版される百科事典で は収録不可能だった膨大な情報が提供され，一般 のインターネットのユーザーによる利用も高い。 その一方で, 紙媒体の百科事典に比べて内容に対 する信頼性への疑問も当然存在する。例えば，英 語版のWikipedialによる日本に関する事項などは, 以 前は玉石混淆の感が否めなかった。最近では，信 憑性に欠ける内容に対しては，典拠を求めるなど の警告がページのトップに現れるようになり，信 頼できる百科事典としての機能を高めようとする 姿勢がうかがわれる。

後者のwikiの例は，主題が狭義に絞られた，特定 のメンバーによるビジネスや会議録，リサーチに おいて利用されるものである。パスワード制によ り投稿も利用も限定され，管理者の目が行き届い ている。意見の交換も速やかにまた頻繁に行われ， 主題となるものの質の向上を目的として形成され るものが多い。

前者のwikiを参照する際の注意点としては,

1. 本文に誤字や文法の誤りがないか。

2. 脚注は正確か。

3.「ノート」や「履歴」を見るのも判断の一つと なる。

4.ページに「警告」がないか。

5. どのような外部リンクを, いくつ持っているか, 
リンク先は信頼性のある情報源となり得るか。 正確性を判断する基準となる。

blogもまた今や重要な学術コミュニケーション の一部である。blogから得られる情報は価值が高く 量も多いが, blogを運営している人の数も膨大であ る。blogに関しては, 次の項目を念頭におくように 注意している。

1. blogの歴史を見る。著者がどのくらいの期間同じ 主題でblogを続けているか。過去の記事も参照す る。

2. 著者のプロフィールを読む。本名を使つている か, 所属先, 教育・勤務の履歴が明確に表示さ れているかも一つの判断材料になる。

3. コメントが多数つけられている記事は, それだ け情報が集まっていることが多い。しかし，コ メントを寄せている人物のプロフィールは明確 でないことが多いので，注意する。

4. wiki之同様, リンクについて調べる。

\subsection{Critical thinking}

ここで，情報リテラシーによく使われるcritical thinkingについて少し言及したい。critical thinkingは, 物事を判断・分析するための評価方法で, 20世紀 の初めに提唱された。最初にcritical thinkingという言 葉を使ったのはフランシス・ベーコンとも言われ る10)。基本的には，偏見や誤った情報に惑わされ ずに, 物事を正しく評価, 分析するための方法で あるが，この評価方法を使用した情報リテラシー は米国では教育界を中心にかなり浸透しており， 文学, 科学, 美術などあらゆる分野にわたって, 早 いところでは小学校の授業から取り入れられてい る。現在ではその一つとしてWebの評価がある。評 価方法はさまざまであるが, Webに関連した方法 を述べているよい例がカリフォルニア大学ロサン

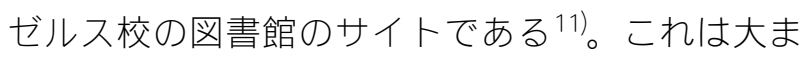

かに，Webの中身とその評価，ソースと日付，構 造に分類し，さらに詳細な項目に分けて評価方法 を述べたものである。Web2.0を評価する上での特 性としてタグが付せられているかどうか, 個人情 報の保護はされているかなどの項目が挙げられて いる。

物事の考え方, 取り組み方は個人によって違い があるが，これは環境のみならず教育によっても 大きく影響される。対象となる事物を批判的に見 るというのではなく, 客観的に観察し分析する習 慣は，情報リテラシーの面で必要な能力を養うこ とになる。この習慣は早いうちから身に付けてお くべきではないだろうか。

\section{6. 結び}

Web2.0は最近までのWebにおけるさまざまな試 みが波にのって普及してきた折，それらを説明す る概念として提唱された用語である。日本では Web2.0を超えてすでに次の動きに関心が移ってい るとする見解もみられると聞くが，米国，特に筆 者の存在する図書館界ではますますWeb2.0環境を 利用した活動が増えてきており，この潮流は当分 続くと思われる。日本においても，一見終わった と見られるこの現象は, 明確に認識されないまで も形を変え，变化し発展していくのではないだろ うか。

それに伴い，関連した新しい技術や現象は目ま ぐるしく登場してくる。また情報量はますます膨 大になり，それに飲み込まれることなく上手に舵 を取っていくためには，情報リテラシーがますま す必須になるだろう。特に，経験年数の浅い図書 館利用者にはインフラストラクチャーとインター ネットの垣根を越えて自由に得られる情報との区 別がつきにくい。また, Second Lifeなどの仮想世界 と現実の世界を自由に出入りするようになると, 
余計に誤情報に関する危機意識が薄まると予想さ れる。情報リテラシーはcritical thinkingに見られるよ うに，なるべく若いうちから身に付けることが望 ましい。これは，単に情報を入手，判断する側の みでなく，情報を管理・運営する側にも必要な基
準であり，情報発信を計画する際に効果的な方法 である。今，Web2.0によってもたらされた環境の もと，あらためて情報リテラシーの見直しを図り， 効果的な運用をしていくことが望まれる。

\section{参考文献}

1) O'Reilly, Tim. "What is Web 2.0: Design patterns and business models for the next generation of software" . O'Reilly Media. http://www.oreillynet.com/pub/a/oreilly/tim/news/2005/09/30/what-is-Web-20.html, (accessed 2008-11-12).

2) “Nielsen//Net ratings". Nielsen Online. http://www.nielsen-online.com/pr/pr_060511.pdf, (accessed 2008-11-12).

3) 工藤絵理子, 片岡真. 次世代OPACの可能性一その特徵と導入への課題一. 情報管理. 2008, vol.51, no.7, p.480-498.

4) Blyberg, John. "Library 2.0 Debased”. Blyberg.net. http://www.blyberg.net/2008/01/17/library-20-debased/, (accessed 2008-11-12).

5) "Story Hour Garden on ALA Island". flickr. http://www.flickr.com/photos/alastaff/2961080919/, (accessed 2008-11-12).

6) Guess, Andy. "Cite Check". INSIDE HIGHER ED. http://www.insidehighered.com/news/2008/07/08/citation, (accessed 2008-11-12).

7) Maron, Nancy L.; Smith K. Kirby. Current models of digital scholarly communication: Results of an investigation conducted by Ithaka for the Association of Research Libraries. http://www.arl.org/bm doc/current-models-report.pdf, (accessed 2008-11-12).

8) University publishing in a digital age. Social commentary on the Ithaka report. http://scholarlypublishing.org/ithakareport/, (accessed 2008-11-12).

9) Kapoun, Jim. Teaching undergrads WEB evaluation: A guide for library instruction. C\&RL news. 1998, vol.59, no.7, http://www.ala.org/ala/mgrps/divs/acrl/publications/crlnews/backissues 1998/julyaugust6/ teachingundergrads.cfm, (accessed 2008-11-12).

10) Bacon, Francis. The Proficience and Advancement of Learning. 1605.

11) “Thinking clitically about Web 2.0 and beyond". UCLA Library Research help. http://www2.library.ucla.edu/libraries/college/11605_12008.cfm, (accessed 2008-11-12).

\section{著者抄録}

日本ではWeb2.0 への関心はすでに薄れていると聞くが, むしろ新技術により創られたWeb2.0の環境はこれ からも発展し続け，利用人口も増加し続けるという考え方にたち，Web2.0によってもたらされる情報リテ ラシーの見直しと実践について焦点をあてたい。まず，Web2.0の特性と情報リテラシーの関係を述べる。 
次に，北米の図書館でのWeb2.0の考えや技術を使用した事例を挙げ，情報リテラシーの面からどのような

点に注意すべきかを論じる。さらにcritical thinkingを紹介し，情報リテラシー教育の重要性を喚起する。

キーワード

Web2.0, Library2.0, ソーシャル・ネットワーキング, 情報リテラシー, クリティカル・シンキング

\section{Author Abstract}

Some information professionals in Japan argue that people already have lost interest in Web2.0, but I contend that the Web2.0 environment, developed by recent technology, will continue to evolve and that the number of Web2.0 users will increase. In this article, I focus on information literacy that needs to be discussed and implemented regarding the nature of Web2.0. First, I discuss relationships between the characteristics of Web2.0 and information literacy. Next, I introduce examples of Web2.0 in academic libraries in North America, and discuss the new aspects of information literacy. Finally, I introduce the concept of critical thinking to raise the importance of education regarding information literacy.

\section{Key words}

Web2.0, Library2.0, social networking, information literacy, critical thinking 